\title{
Kinetic Behaviour of the Activated Sludge Process Used for Treating Composite Chrome Tannery Wastewater
}

\author{
Supriyo Goswami, Debabrata Mazumder* \\ Civil Engineering Department, Indian Institute of Engineering Science and Technology, \\ Shibpur P.O.- Botanic Garden, Howrah - 711 103, India \\ Received: June 8, 2015 \\ Accepted: August 25, 2015
}

\begin{abstract}
Chrome tannery wastewater poses a serious environmental threat due to its high chemical oxygen demand (COD), bio-chemical oxygen demand $\left(\mathrm{BOD}_{5}\right)$, nitrogen, total suspended solids (TSS), chromium, sulphide, chloride, etc. As a result, the composite chrome tannery wastewater is not treated satisfactorily in most cases owing to various toxic/inhibitory substances. Out of various biological methods available for the treatment of composite chrome tannery wastewater, the activated sludge process (ASP) is a proven technology. The process design of the ASP reactor with rational approach always warrants authentic values of kinetic coefficients regarding substrate removal and biomass growth. Therefore, the kinetic behaviour of substrate (i.e. COD) removal and biomass growth must be established prior to use of any model. Apart from this, the biodegradation potential of the concerned wastewater needs to be adjudged to take appropriate measures during treatment. The present study was performed to examine the treatability of the composite chrome tannery wastewater using an acclimated suspended biomass under batch mode of operation. The study also aims to determine the kinetic co-efficient for biodegradation based on the most favourable kinetic model. A laboratory-scale ASP reactor was run for conducting the batch study on COD removal from composite tannery wastewater and also for determining the kinetic coefficients. The results of several batch experiments revealed the efficacy of the ASP system in treating composite chrome tannery wastewater, but some inhibition was also noticed. Consequently, the Haldane growth kinetic model was found best fitting for biodegradation of chrome tannery wastewater using mixed microorganisms. The batch study was carried out under varying batch periods to determine five kinetics constants, viz. $\mathrm{K}_{\mathrm{s}}, \mathrm{k}, \mathrm{k}_{\mathrm{i}}, \mathrm{Y}$, and $\mathrm{k}_{\mathrm{d}}$ from the experimental data. The values of all the kinetic coefficients are tallying with past kinetic studies on composite tannery wastewater.
\end{abstract}

Keywords: activated sludge process, kinetic study, composite tannery wastewater, COD removal, Haldane kinetics, kinetic co-efficient

\section{Introduction}

The chrome tanning process generates a considerable amount of wastewater-containing biodegradable organic matters and inhibitory substances like chromium, chloride

*e-mail: debabrata@civil.iiests.ac.in sulphide, etc. Although segregation of various waste streams is necessary to follow-up physico-chemical or biological methods accordingly, composite tannery wastewater is apparently incompatible for biological treatment. The process of segregation and treatment of individual waste requires additional high cost, which is not affordable for small/medium-scale tanneries. Under this scenario, the 
Table 1. Results of characterization of composite chrome tannery wastewater.

\begin{tabular}{|l|c|c|c|c|c|c|c|c|c|c|c|}
\hline Parameter & $\mathrm{pH}$ & $\mathrm{COD}$ & $\mathrm{TS}$ & $\mathrm{TDS}$ & $\begin{array}{c}\mathrm{TKN} \\
\text { (as N) }\end{array}$ & $\begin{array}{c}\text { Organic } \\
\text { Nitrogen } \\
(\text { as N) }\end{array}$ & $\mathrm{NH}_{3}-\mathrm{N}$ & $\begin{array}{c}\mathrm{Cl}^{-} \\
\left.\text {(as } \mathrm{Cl}^{-}\right)\end{array}$ & $\begin{array}{c}\mathrm{PO}_{4}{ }^{3-} \\
\text { (as } \mathrm{P})\end{array}$ & $\mathrm{Cr}^{+6}$ & $\mathrm{SO}_{4}^{2-}$ \\
\hline Maximum & 8.8 & 4,345 & 13,362 & 10,842 & 354 & 314 & 215 & 4,248 & 13.85 & 14.1 & 2,081 \\
\hline Minimum & 8.3 & 25,280 & 10,254 & 7,792 & 235 & 50 & 40 & 3,049 & 4.94 & 0.3 & 1,590 \\
\hline Average & 8.6 & 11,981 & 11,414 & 9,723 & 304 & 163 & 129 & 3,614 & 10.49 & 4.475 & 1,961 \\
\hline
\end{tabular}

activated sludge process is a widely applied biological method for the treatment of mixed wastewater from tannery units after pre-treatment. In most cases, biological treatment of pre-treated chrome tannery wastewater was found unsatisfactory due to poorly acclimated biomass. Hence, there is a possibility of discarding the pre-treatment step by adequate acclimation of the biomass under the inhibitory environment of composite chrome wastewater. Design of such a system necessitates rational values of kinetic coefficient, which can be determined from laboratory study. A number of research studies have already been reported to determine various kinetic coefficients, i.e. $\mathrm{K}_{\mathrm{s}}$ (half saturation constant), $\mathrm{k}$ (maximum specific substrate utilization rate), $\mathrm{Y}$ (yield coefficient), and $\mathrm{k}_{\mathrm{d}}$ (endogenous decay constant) pertaining to the treatment of chrome tannery wastewater [1-6] both in batch or continuous mode of operation.

Analyzing the results of previous studies, it was found that the Monod model well suited the aerobic degradation of tannery wastewater using a mixed microbial consortium. It is also evident from past research that the kinetic behaviour of aerobic biological treatment of chrome tannery wastewater differs widely depending upon the characteristics of wastewater and heterogeneous bacterial population [3]. Recently a few research studies were carried out on the laboratory-scale activated sludge process treating chrome tannery wastewater for determination of various bio-kinetic coefficients [7,8]. The kinetic coefficients were determined by applying modified Monod growth kinetic approach. A fixed bed bio-film reactor has also been studied extensively for determination of various biokinetic coefficients [9]. Experimental results revealed that the attached growth process may be an alternative treatment option for composite chrome tannery wastewater treatment to ensure higher organic removal efficiency.

However, effective design and operation of a biological system - especially for treatment of composite chrome tannery wastewater containing toxic inhibitory substances (mainly chromium) - requires a realistic model incorporating both substrate removal and biomass growth rate.

In this context, it is imperative to state that no kinetic study has been reported so far exclusively for the treatment of composite chrome tannery wastewater under a wellacclimated activated sludge process (ASP) system. Looking into this matter, the present research was undertaken first to establish the growth curve for the mixed microorganism under composite chrome tannery waste- water. Secondly, it was aimed to fit the batch study results in one non-inhibitory and one inhibitory kinetic model. The kinetic coefficients were determined for the most appropriate model, accordingly. A simple batch ASP system was operated in this study after acclimation of the biomass under composite chrome tannery wastewater.

\section{Materials and Methods}

\section{Characterization of Composite Tannery Wastewater}

In order to characterize the composite chrome tannery wastewater, samples were collected from a common effluent treatment unit in the Calcutta Leather Complex (CLC) in Kolkata. Ten litres of raw wastewater emanating from the composite chrome tannery unit was collected for six consecutive weeks. The collected samples were analyzed for various characteristic parameters viz. $\mathrm{pH}$, total solid (TS), total dissolved solids (TDS), chemical oxygen demand (COD), total Kjeldahl nitrogen (TKN), $\mathrm{NH}_{3}-\mathrm{N}$, total phosphorus, chlorides, sulphate, $\mathrm{Cr}^{+6}$, etc. The results of characterization are shown in Table 1.

\section{Acclimation of Biomass}

Firstly, a soil sample from a tannery wastewater disposal site (CLC complex) was collected for growing the seed. After addition of water, the mixture was allowed to settle for $15 \mathrm{~min}$ and the supernatant was transferred to a $10.0 \mathrm{~L}$ capacity bucket. An adequate amount of water was also added to make up the final volume of 9.0 L. Aeration was provided by means of two aquarium pumps. As part of acclimation, a fixed volume of feed containing gradually increasing amounts of tannery wastewater and balance quantity of domestic wastewater was given regularly. Apart from that, each nutrient solutions of $\left(\mathrm{K}_{2} \mathrm{HPO}_{4}+\mathrm{KH}_{2} \mathrm{PO}_{4}\right)$, $\mathrm{CaCl}_{2}, \mathrm{MgSO}_{4}$, and $\mathrm{FeCl}_{3}$ are added at the rate of $1 \mathrm{ml} / \mathrm{L}$ of the reactor content separately to facilitate biomass growth. The biomass growth was measured in terms of mixed liquor suspended solids/mixed liquor volatile suspended solids (MLSS/MLVSS) concentration in the unit. The organic removal was measured in terms of chemical oxygen demand (COD). The acclimation was carried out over a period of approximately three months. 
Table 2. The results of batch study with composite chrome tannery wastewater.

\begin{tabular}{|c|c|c|c|}
\hline $\begin{array}{c}\text { Influent COD } \\
(\mathrm{mg} / \mathrm{L})\end{array}$ & $\begin{array}{l}\text { Batch period } \\
\text { (h) }\end{array}$ & $\begin{array}{l}\text { MLSS } \\
(\mathrm{mg} / \mathrm{L})\end{array}$ & $\begin{array}{c}\text { Effluent COD } \\
(\mathrm{mg} / \mathrm{L})\end{array}$ \\
\hline \multirow{5}{*}{140} & 0 & 540 & 140 \\
\hline & 2.5 & 568.8 & 92 \\
\hline & 5 & 580 & 72 \\
\hline & 7.5 & 588.6 & 59 \\
\hline & 10 & 594 & 50 \\
\hline \multirow{6}{*}{191} & 0 & 556.8 & 191 \\
\hline & 2.5 & 566.4 & 175 \\
\hline & 5 & 552.74 & 197.76 \\
\hline & 7.5 & 582 & 155 \\
\hline & 10 & 599.4 & 120 \\
\hline & 24 & 653.4 & 30 \\
\hline \multirow{6}{*}{217.53} & 0 & 600 & 217.53 \\
\hline & 2.5 & 608 & 174.68 \\
\hline & 5 & 658.52 & 120 \\
\hline & 7.5 & 672.9 & 96 \\
\hline & 10 & 687 & 72.5 \\
\hline & 24 & 689 & 69 \\
\hline \multirow{6}{*}{323} & 0 & 466 & 323.008 \\
\hline & 2.5 & 479 & 299.9 \\
\hline & 5 & 502 & 263.8 \\
\hline & 7.5 & 522 & 230 \\
\hline & 10 & 540 & 200 \\
\hline & 24 & 456 & 339 \\
\hline \multirow{6}{*}{422} & 0 & 656 & 422 \\
\hline & 2.5 & 665.5 & 405 \\
\hline & 5 & 663 & 408 \\
\hline & 7.5 & 667 & 402 \\
\hline & 10 & 698 & 350 \\
\hline & 24 & 754 & 257 \\
\hline
\end{tabular}

\section{Experimental Steps for Batch Kinetic Study}

Before starting the batch study, acclimated biomass of about $9 \mathrm{~L}$ volume was taken in a plain bucket and was aerated adequately with two aqua pumps. Then the volume of composite wastewater was adjusted in such a way that the initial COD concentration was set out in the range of (100$500) \mathrm{mg} / \mathrm{L}$. The biomass (MLSS) concentration was also adjusted considering the COD/MLSS ratio in the range of
(0.2-0.4). $\mathrm{pH}$ in the reactor was also adjusted between 7.0 and 7.5. In the course of batch study both COD and MLSS concentrations were measured and recorded at the end of various batch periods. Biomass growth was recorded as MLSS in $\mathrm{mg} / \mathrm{L}$ against reduction in COD values. The samples of $50 \mathrm{~mL}$ volume were collected from the batch reactor at different time intervals, viz. 2.5, 5, 7.5, 10, and $24 \mathrm{hr}$. All the parameters viz. pH, MLSS, and COD were measured as per Standard Methods [10].

\section{Results and Discussion}

\section{Batch Performance Study}

The batch study was performed with a variable initial COD and MLSS concentration. The specific growth rate of biomass was measured at the end of each batch period against effluent substrate concentration as shown in Fig. 1. The microbial growth pattern under composite chrome tannery wastewater conditions clearly indicates that there is significant inhibition due to the presence of some toxic substance in the wastewater. Fig. 1 also resembles the pattern as represented by Haldane-type of growth kinetic model. The results of batch study are shown in Table 2 .

\section{Evaluation of Kinetic Coefficients}

Since the specific growth curve in Fig. 1 clearly demonstrated an inhibition, the kinetic coefficients were determined from the approach of Haldane's model. In Haldane's kinetic model there are two distinct zones: inhibition, and non-inhibition. The relevant kinetic coefficients under Haldane's model are half saturation constant $\left(\mathrm{K}_{\mathrm{s}}, \mathrm{mg} / \mathrm{L}\right)$, maximum specific substrate utilization rate $(\mathrm{k}, \mathrm{mg}$ $\mathrm{COD} / \mathrm{mg} \mathrm{MLSS} /$ day), yield coefficient (Y, mg MLSS/ mg COD), endogenous decay constant $\left(\mathrm{k}_{\mathrm{d}}, \mathrm{d}^{-1}\right)$, and inhibition constant $\left(\mathrm{k}_{\mathrm{i}}, \mathrm{mg} / \mathrm{L}\right)$. In order to evaluate $\mathrm{K}_{\mathrm{s}}$ and $\mathrm{k}$, batch study data was considered in the non-inhibition zone, i.e. under low COD concentration. Hence the values of XT/ $\left(\mathrm{S}_{0}-\mathrm{S}\right)$ were plotted against $1 / \mathrm{S}$ as shown in Fig. 2, and $\mathrm{K}_{\mathrm{s}}$ as well as $\mathrm{k}$ were evaluated from the slope and intercept accordingly. Similarly, the value $\left(\mathrm{X}-\mathrm{X}_{0}\right) / \mathrm{XT}$ are plotted

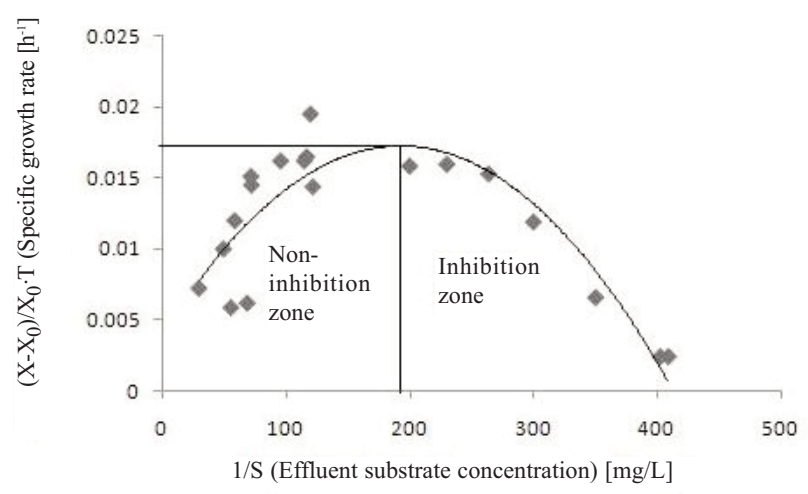

Fig. 1. Biomass growth curve under composite chrome tannery wastewater conditions. 
Table 3. Comparison of kinetic co-efficients for biodegradation of chrome tannery wastewater.

\begin{tabular}{|c|c|c|c|c|c|}
\hline $\mathrm{k}\left(\mathrm{d}^{-1}\right)$ & $\mathrm{K}_{\mathrm{s}}(\mathrm{mg} / \mathrm{L})$ & $\mathrm{Y}(\mathrm{mg} / \mathrm{mg})$ & $\mathrm{k}_{\mathrm{d}}\left(\mathrm{d}^{-1}\right)$ & $\mathrm{k}_{\mathrm{i}}(\mathrm{mg} / \mathrm{L})$ & References \\
\hline $1.56-2.42$ & $113-142$ & $0.484-0.613$ & $0.055-0.084$ & - & {$[6]$} \\
\hline 0.295 & 832.68 & 0.915 & 0.295 & - & {$[1]$} \\
\hline 0.952 & 170.83 & 0.36 & 0.084 & - & {$[4]$} \\
\hline 1.42 & 426 & 0.384 & 0.12 & - & {$[5]$} \\
\hline 3.125 & 488 & 0.64 & 0.035 & - & {$[3]$} \\
\hline 1.66 & 1132 & 0.22 & 0.05 & - & {$[8]$} \\
\hline 1.2 & 209 & 0.18 & 1.53 & -039 & {$[9]$} \\
\hline 2.584 & 50 & 0.854 & 0.024 & 40 & This study \\
\hline 0.2 & 23.02 & 0.680 & - & - & - \\
\hline
\end{tabular}

"." the value is not reported

against $\left(\mathrm{S}_{0}-\mathrm{S}\right) / \mathrm{XT}$ as shown in Fig. 3 and $\mathrm{Y}$, as well as $\mathrm{k}_{\mathrm{d}}$ were determined from the slope and intercept, respectively. It is observed from Figs. 2 and 3 that $\mathrm{k}=0.008 \mathrm{~h}^{-1}$ or $0.2 \mathrm{~d}^{-1}$ and $\mathrm{K}_{\mathrm{s}}=23.02 \mathrm{mg} / \mathrm{L}, \mathrm{Y}=0.680 \mathrm{mg} / \mathrm{mg}$, and $\mathrm{k}_{\mathrm{d}}=0.001 \mathrm{~h}^{-1}$ or $0.024 \mathrm{~d}^{-1}$. In order to calculate inhibition constant $\mathrm{k}_{\mathrm{i}}$ the value $\left(\mathrm{X}-\mathrm{X}_{0}\right) / \mathrm{XT}$ were plotted against $\mathrm{S}$ as shown in Fig. 4, and the value of $\mathrm{k}_{\mathrm{i}}$ was evaluated from the slope of best-fit line. From Fig. 4 it is observed that the value of $k_{i}$ is $40 \mathrm{mg} / \mathrm{L}$. The kinetic coefficients obtained from batch kinetic study have been compared with the earlier observations in this regard as shown in Table 3.

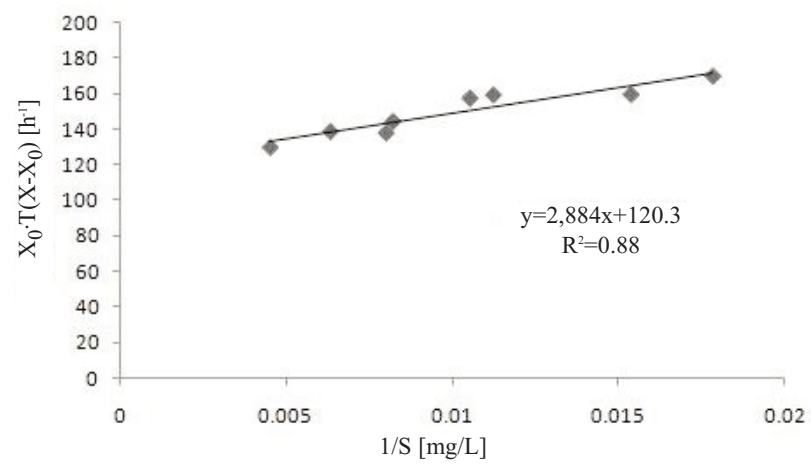

Fig. 2. Determination of kinetic coefficients $\mathrm{K}_{\mathrm{s}}$ and $\mathrm{k}$.

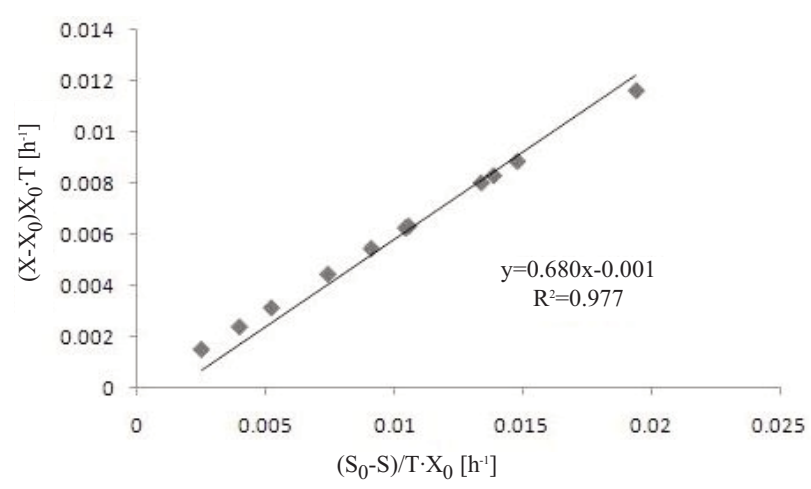

Fig. 3. Determination of kinetic coefficients $\mathrm{Y}$ and $\mathrm{k}_{\mathrm{d}}$.
The kinetic coefficients were determined according to Haldane's model showing $\mathrm{k}, \mathrm{K}_{\mathrm{s}}, \mathrm{Y}, \mathrm{k}_{\mathrm{d}}$, and $\mathrm{k}_{\mathrm{i}}$ as $0.2 \mathrm{~d}^{-1}$, $23.02 \mathrm{mg} / \mathrm{L}, 0.680 \mathrm{mg} / \mathrm{mg}, 0.024 \mathrm{~d}^{-1}$, and $40 \mathrm{mg} / \mathrm{L}$, respectively. The values of kinetic coefficients $\left(\mathrm{k}, \mathrm{Y}\right.$, and $\mathrm{k}_{\mathrm{d}}$ ) are within the range of their values reported by earlier researchers for chrome tannery wastewater. A significantly low value of Half saturation constant $\left(\mathrm{K}_{\mathrm{s}}\right.$; i.e. $\left.24 \mathrm{mg} / \mathrm{L}\right)$ was obtained for carbon oxidation under non-inhibitory conditions. This great inconsistency in $\mathrm{K}_{\mathrm{s}}$ value may possibly have occurred due to low initial substrate concentration under non-inhibitory environment. The value of $\mathrm{k}_{\mathrm{i}}$ clearly indicated that inhibition started even at a COD concentration of $40 \mathrm{mg} / \mathrm{L}$. It also implies that the composite chrome tannery wastewater is highly toxic, presumably because of chromium and sulphur species.

\section{Conclusion}

The kinetic behaviour of acclimated microorganisms under composite chrome tannery wastewater conditions was explored in the present study. The specific growth rate $v s$. substrate concentration curve ( $\mu v s$. S) shows a microbial growth pattern similar to Haldane type at the high substrate concentration. The inhibition is confirmed by the

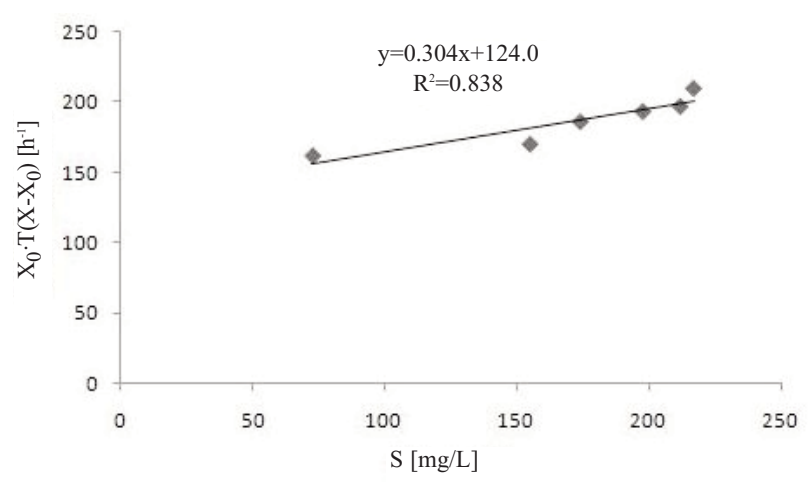

Fig. 4. Determination of inhibition constant $\mathrm{k}_{\mathrm{i}}$. 
increase in growth rate, sharply followed by rapid decline in the same. Although the kinetic co-efficients are obtained in the appropriate range, they are very much distinct - especially for the composite chrome tannery wastewater. The values of the kinetic co-efficient revealed that the biodegradation of composite chrome tannery wastewater was essentially a slow process. However, the rate of biodegradation may be enhanced by means of further extensive acclimation. A thorough investigation is also needed to establish the inhibition constant for the biodegradation of composite chrome tannery wastewater.

\section{References}

1. DEBABRATA B., PARIMAL C., LALITARAURI R. Continuous removal of chromium from tannery wastewater using activated sludge process - Determination of kinetic parameters. Indian J. Chem. Techn., 19, 32, 2012.

2. DURAI G., RAJAMOHAN N., KARTHIKEYAN C., RAJASIMMAN M. Kinetics Studies on Biological Treatment of Tannery Wastewater Using Mixed Culture. Journal of Environmental Science and Technology, 4, (1), 1, 2011.

3. HAYDAR.S., AZIZ. J.A. Kinetic Coefficients for the Biological Treatment of Tannery Wastewater Using
Activated Sludge Process. Pak. J. Egg. \& Appl. Sci., 5, 39, 2009.

4. MAZUMDER D., MUKHERJEE S., RAY P. K. Treatment of tannery waste water in a hybrid bioreactor. Int. J. Environ. Pollut., 34, 43, 2008.

5. PRAKASH N.B. Bio-kinetic Studies of Tannery Effluent under Aerobic Oxidation Process. J. Sci. Ind. Res. India, 60, 344, 2001.

6. RAM B., BAJPAI P.K., PARWANA H.K. Kinetics of chrome-tannery effluent treatment by the activated sludge system. Process Biochem., 35, 255, 1999.

7. ELMAGD A.M.A, MAHMOUD M.S., Tannery Wastewater Treatment Using Activated Sludge Process System (Lab Scale Modeling). International Journal of Engineering and Technical Research, 2, (5), 21, 2014.

8. PRAKASH N B. Bio-kinetic Studies in the Treatment of Tannery Effluent. Journal of Sustainable Development, 6, (6), 89, 2013

9. GOSWAMI S., SARKAR S., MAZUMDER D. Determination of Kinetic co-efficient for Chrome Tannery Wastewater Treatment in an Aerobic Bio-film Reactor, International conference on Recent trends and Challenges in Civil Engineering, ISBN: 978-93-80635-16-3, India, 2014.

10. American Public Health Association (APHA, 1995). Standard Methods for the examination of Water and Wastewater $\left(22^{\text {nd }}\right.$ edn.). APHA, AWWA, WPCF, Washington, D.C. 1995. 
